\title{
NITROGEN RATES ON GROWTH, YIELD AND NITRATE FOLIAR CONTENT OF ARUGULA ${ }^{1}$
}

\author{
PAULO HENRIQUE SOARES SILVA ${ }^{2}$, ARTHUR BERNARDES CECÍLIO FILHO ${ }^{2 *}$, ISAÍAS DOS SANTOS REIS ${ }^{2}$, \\ SÉRGIO MANUEL RUGELES REYES ${ }^{2}$, MARA CRISTINA PÊSSOA DA CRUZ ${ }^{2}$
}

\begin{abstract}
Nitrogen is the second nutrient most demanded by arugula. However, the positive effect it has on yield can negatively impact the quality of this vegetable, with negative effects on human health. Two experiments (summer and autumn) were carried out to evaluate the effect of $\mathrm{N}$ rates $(0,50,100,150,200$ and $250 \mathrm{~kg} \mathrm{ha}^{-1}$ ) on the arugula growth, yield and quality (nitrate content). Each experiment was set up in a randomized block design with four replications. Increasing rates of $\mathrm{N}$ reflected positively on leaf $\mathrm{N}$ content and thus, higher and desirable values of height, leaf number, leaf area and plant dry mass were obtained in both growing seasons. Consequently, the yield had significant increase, which $\mathrm{N}$ was maximized in summer $\left(4.9 \mathrm{~kg} \mathrm{~m}^{-2}\right)$ and autumn $\left(2.6 \mathrm{~kg} \mathrm{~m}^{-2}\right)$ and leaf $\mathrm{N}$ of 29.4 and $27.0 \mathrm{~g} \mathrm{~kg}^{-1}$, respectively, at rates of 250 and $213 \mathrm{~kg} \mathrm{ha}^{-1}$ and both growing seasons. The higher rate the higher foliar nitrate content of arugula, in summer (2931.3 mg kg-1) and autumn (4218.4 $\left.\mathrm{mg} \mathrm{kg}^{-1}\right)$. The foliar nitrate content in both crop season do not reach the risk level to human being heath.
\end{abstract}

Keywords: Eruca sativa Mill. Leaf vegetable. Nitrate. Quality.

\section{DOSES DE NITROGÊNIO NO CRESCIMENTO, PRODUTIVIDADE E TEOR FOLIAR DE NITRATO DA RÚCULA}

RESUMO - O nitrogênio (N) é o segundo nutriente com maior demanda pela rúcula. No entanto, o efeito positivo que ele tem sobre o rendimento pode afetar negativamente a qualidade desse vegetal, com efeitos negativos para saúde humana. Essa resposta da planta depende da cultivar, do ambiente de cultivo e do manejo da colheita, cuja interação não é clara na literatura. Dois experimentos em campo (verão e outono), estabelecidos em delineamento de blocos casualizados com quatro repetições, foram realizados com o objetivo de avaliar o efeito das doses de $\mathrm{N}\left(0,50,100,150,200\right.$ e $\left.250 \mathrm{~kg} \mathrm{ha}^{-1}\right)$ no crescimento, produção e qualidade da rúcula. As doses crescentes de $\mathrm{N}$ refletiram positivamente no teor de $\mathrm{N}$ nas folhas e, portanto, foram obtidos valores mais elevados e desejáveis de altura, número de folhas, área foliar e massa seca das plantas em ambas as épocas de cultivo. Consequentemente, foi observado aumento significativo da produtividade, o qual foi maximizado no verão $\left(4,9 \mathrm{~kg} \mathrm{~m}^{-2}\right)$ e no outono $\left(2,6 \mathrm{~kg} \mathrm{~m}^{-2}\right)$ e $\mathrm{N}$ foliar de 29,4 e $27,0 \mathrm{~g} \mathrm{~kg}^{-1}$, respectivamente, nas doses de 250 e $213 \mathrm{~kg} \mathrm{ha}^{-1}$ e ambas épocas de cultivo. Quanto maior a dose, maior o teor de nitrato foliar da rúcula, no verão $\left(2931,3 \mathrm{mg} \mathrm{kg}^{-1}\right)$ e outono $\left(4218,4 \mathrm{mg} \mathrm{kg}^{-1}\right)$. Nas duas estações, quanto maior a dose, maior o teor de nitrato, contudo, nas duas safras não atingiu o nível de risco para a saúde humana.

Palavras-chave: Eruca sativa Mill. Hortaliça folhosa. Nitrato. Qualidade.

\footnotetext{
${ }^{*}$ Corresponding author

${ }^{1}$ Received for publication in $11 / 04 / 2020$; accepted in 03/08/2021.

Paper extracted from the master dissertation of the first author.

${ }^{2}$ Department of Crop Production Sciences, Universidade Estadual Paulista, Jaboticabal, SP, Brazil; phsoares18@yahoo.com.br - ORCID: 0000-0001-5246-2723, arthur.cecilio@unesp.br - ORCID: 0000-0002-6706-5496, isaias.agro@hotmail.com - ORCID: 0000-0002-63816053, smrugelesr@gmail.com - ORCID: 0000-0002-7464-3864, mcp.cruz@unesp.br - ORCID: 0000-0002-6000-878X.
} 


\section{INTRODUCTION}

Nitrogen $(\mathrm{N})$ is the second most demanded nutrient for arugula (Eruca sativa Miller) (GRANGEIRO et al., 2011). As in any other crop, when in adequate levels, $\mathrm{N}$ stimulates vegetative growth, expands the photosynthetically active area, and provides more attractive and succulent coloured leaves (AGUIAR JÚNIOR et al., 2010; NASCIMENTO et al., 2017).

In arugula crops, $\mathrm{N}$ deficiency is rarely observed as it is a species considered very responsive to nutrient supply (PURQUERIO et al., 2007; STEINER et al., 2011; SILVA et al., 2020) which leads producers to apply high rates. In excess, due to the high capacity of $\mathrm{N}$ to modify morphological and consequently, physiological aspects of the plant, it favours an imbalance between shoot and root system growth, with negative implications on processes such as respiration, nutrition, photosynthesis, mechanisms of growth, defense to biotic and abiotic factors, among others. Of course, these and other implications lead to lost productivity; however, this may not be so quickly affected, as leafy vegetables have a high response and ability to accumulate nutrients without toxicity.

Excess of $\mathrm{N}$ has other implications as important as that mentioned above on productivity. Firstly, the excessive use of $\mathrm{N}$ fertilizer results in low $\mathrm{N}$ use efficiency and has no yield benefits (AHMED et al., 2017). The cost of fertilizer and the operation of its application is about $30-35 \%$ of the operating production cost of the arugula (REZENDE et al., 2005; REZENDE et al., 2009). Secondly, there is a strong indication that excess rates of $\mathrm{N}$ result in higher nutrient losses, which, in turn, have greater potential for eutrophication of water resources and increase the emissions of the greenhouse gases (WARD, 2009; LIU et al., 2014; WANG et al., 2014). Thirdly, are possible negative effects on food quality. When the absorption by the plant is greater than actual demand, characterising the excess, the nutrient is stored as nitrate (NURZYNSSKAWIERDAK, 2009). Nitrate is not harmful to man, but under potentiating conditions present in the human organism, nitrate can combine with amines, and producing nitrosamines that are mutagenic and carcinogenic, or possibly achieving the bloodstream and cause methaemoglobinaemia (KHAN et al., 2013; OLLÚA; LOGEGARAY; CHIESA, 2016).

Arugula is a short-cycle leafy vegetable and belongs to a group that has a high capacity to accumulate nitrate (NURZYŃSKA-WIERDAK, 2009; BARROS JÚNIOR et al., 2020). According to Qadir et al. (2017), studies show that vegetables provide approximately 40 - $92 \%$ of the average daily intake of nitrate by humans, and according to Liu et al. (2014), the arugula, spinach and lettuce are some of the richest sources of nitrate in the human diet. However, nitrate accumulation is not only genotype dependent but highly influenced by the environment and crop management (LIU et al., 2014; STAGNARI; GALIENI; PISANTE, 2015; AHMED et al., 2017).

Consequently, because the amount of $\mathrm{N}$ supplied to the arugula affects its productivity and quality (NURZYNSSKA-WIERDAK, 2009), it is pertinent to study locally the rationalization of the $\mathrm{N}$ fertilization to arugula and not extrapolate the results obtained under different conditions of management, weather and cultivar. According to Liu et al. (2014), rationalizing fertilizer application is an important issue for sustainable agriculture.

In this context, the objective was to evaluate the agronomic performance and quality of arugula as a function of $\mathrm{N}$ rates.

\section{MATERIALS AND METHODS}

\section{Experimental site}

Two experiments were conducted under field conditions $\left(21^{\circ} 15 ' 22^{\prime}\right.$ 'S, $48^{\circ} 18^{\prime} 58^{\prime \prime} \mathrm{W}$ and altitude of $575 \mathrm{~m}$ a.s.1.) in Jaboticabal, Brazil, from 24 January to 3 March 2017 (summer, Experiment 1) and from 10 May to 15 June 2018 (autumn, Experiment 2).

The climate of the region is classified as subtropical, rainy during the summer and relatively dry in the winter. The annual means for precipitation and temperature and maximal and minimal temperatures are $1424.6 \mathrm{~mm}, 22.2^{\circ} \mathrm{C}, 28.9^{\circ} \mathrm{C}$ and $16.8^{\circ} \mathrm{C}$, respectively. The table 1 shows the climatic parameters along the two crops. The data were obtained from the agrometeorological station at UNESP-FCAV, Jaboticabal - SP.

Table 1. Temperature (Temp.), relative humidity (RH), rainfall (R) and solar radiation (SR) in Summer (S) and Autumn (A) experiments.

\begin{tabular}{ccccccccc}
\hline & \multicolumn{2}{c}{ Temp. $\left({ }^{\circ} \mathrm{C}\right)$} & \multicolumn{2}{c}{$\mathrm{RH}(\%)$} & \multicolumn{2}{c}{$\mathrm{R}(\mathrm{mm})$} & \multicolumn{2}{c}{$\left.\mathrm{SR}(\mathrm{MJ} \mathrm{m})^{-2}\right)$} \\
& $\mathrm{S}$ & $\mathrm{A}$ & $\mathrm{S}$ & $\mathrm{A}$ & $\mathrm{S}$ & $\mathrm{A}$ & $\mathrm{S}$ & $\mathrm{A}$ \\
\hline Maximum & 31.1 & 27.7 & 92.8 & 87.5 & - & - & - & - \\
Average & 24.4 & 20.4 & 74.1 & 64.1 & - & - & 22.5 & 14.7 \\
Minimum & 19.6 & 14.3 & 45.1 & 36.3 & - & - & - & - \\
Total & - & - & - & - & $276(18)^{1}$ & $7.2(1)$ & 902 & 529 \\
\hline
\end{tabular}

${ }^{1}$ The number in parentheses corresponds to rainy days. 
According to the classification of Santos et al. (2018), the soil of the area is a typical Oxisol with clayey texture (660 $\mathrm{g} \mathrm{kg}^{-1}$ of clay), and the soil chemical analysis at the 0 to $20 \mathrm{~cm}$ profile, were: $\mathrm{pH}$ $(\mathrm{CaCl} 2)=5.3$ and 5.6 ; organic matter $=27$ and $17 \mathrm{mg}$ $\mathrm{dm}^{-3} ; \mathrm{P}_{(\text {Resin })}=9$ and $31 \mathrm{mg} \mathrm{dm}^{-3} ; \mathrm{S}=12$ and $9 \mathrm{mg}$ $\mathrm{dm}^{-3} ; \mathrm{Ca}=42$ and $22 \mathrm{mmol}_{\mathrm{c}} \mathrm{dm}^{-3} ; \mathrm{Mg}=15$ and 10 $\mathrm{mmol}_{\mathrm{c}} \mathrm{dm}^{-3} ; \mathrm{K}=5.9$ and $3.3 \mathrm{mmol}_{\mathrm{c}} \mathrm{dm}^{-3} ; \mathrm{H}+\mathrm{Al}=23$ and $15 \mathrm{mmol}_{\mathrm{c}} \mathrm{dm}^{-3}$; and base saturation $(\mathrm{V})=73$ and $71 \%$.

\section{Experimental design and treatments}

The two experiments differed as to the season of cultivation (summer and autumn). In both, the same six $N$ rates $(0,50,100,150,200$ and $250 \mathrm{~kg} \mathrm{ha}^{-1}$ ) were evaluated, in a randomised block design, with four replications. The $\mathrm{N}$ source used was urea $(45 \% \mathrm{~N})$.

Each experimental unit was $3.0 \mathrm{~m}$ in length (12 transversal lines in relation to the length of bed) and $1.0 \mathrm{~m}$ wide, giving a total area of $3 \mathrm{~m}^{2}$. The useful area for data collection corresponded to the eight central lines $\left(2 \mathrm{~m}^{2}\right)$.

\section{Crop management}

According to the base saturation index, there was no need to apply limestone prior to both experiments. Planting fertilization was performed based on soil analysis, following the recommendation for fertilization and liming in the state of São Paulo (TRANI; PASSOS; AZEVEDO FILHO, 1997), thus were applied $400 \mathrm{~kg} \mathrm{ha}^{-1}$ of $\mathrm{P}_{2} \mathrm{O}_{5}$ (simple superphosphate) and $50 \mathrm{~kg} \mathrm{ha}^{-1}$ of $\mathrm{K}_{2} \mathrm{O}$ (potassium chloride). Additionally, boric acid was sprayed onto the bed soil to provide $1 \mathrm{~kg} \mathrm{ha}^{-1}$ of $\mathrm{B}$. Except in plots with a rate of $0 \mathrm{~kg} \mathrm{ha}^{-1}$ of $\mathrm{N}$, was applied $50 \mathrm{~kg} \mathrm{ha}^{-1}$ of $\mathrm{N}$ as planting fertilization for all experimental units of others treatments. It were incorporated fertilizers into the soil and the 'Folha Larga' arugula was sown in grooves approximately $0.015 \mathrm{~m}$ deep, spaced $0.25 \mathrm{~m}$ apart. Seedling emergence occurred three days after sowing for both experiments. Two thinning processes were performed to adjust the spacing between plants to $0.05 \mathrm{~m}$, one at four days after emergence (DAE) and other at 10 DAE. The topdressing was only $\mathrm{N}$ (except for the 0 and $50 \mathrm{~kg} \mathrm{ha}^{-1} \mathrm{~N}$ treatments) in an amount to complete the total established in the treatments, discounting the $50 \mathrm{~kg} \mathrm{ha}^{-1}$ of $\mathrm{N}$ applied at planting fertilization. The remainder of $\mathrm{N}$ fertilization was sliced equally and the amounts applied at 10 and 17 DAE. Irrigation was performed by spraying, according to the water needs of the crop, in order to maintain soil moisture close to field capacity.

\section{Evaluated characteristics}

At arugula harvest were evaluated, the plant height (beginning of petiole up to the top of highest leaf), number of leaves, leaf area (leaf area integrator LI-COR 3100) and shoot dry mass. In order to obtain the dry mass of the aerial part, the plants were washed, dried in an oven with forced air circulation at $65^{\circ} \mathrm{C}$ to $70{ }^{\circ} \mathrm{C}$ until a constant mass was obtained. Then, the dry matter was measured accurately to two decimal places. Yield, expressed in $\mathrm{kg} \mathrm{m}^{-2}$, was estimated based on the fresh mass of arugula plants obtained immediately after harvesting between 6 a.m. and 7 a.m.

The foliar $\mathrm{N}$ content was measured according to the methodology of Miyazawa et al. (2009). After washing the leaves in deionized water, they were dried in an oven with forced air circulation from $65{ }^{\circ} \mathrm{C}$ to $70{ }^{\circ} \mathrm{C}$ until a constant mass. After drying, the material was ground and weighed $(0.1 \mathrm{~g})$. Sulphur digestion was performed and the $\mathrm{N}$ content determined.

To evaluate the nitrate content in the shoot, six plants were randomly collected in the useful area of each experimental unit, in the morning between 5.30 a.m. and 6.30 a.m. Nitrate content was determined according to Mantovani et al. (2005), using the following procedure. In $50 \mathrm{~mL}$ Falcon tubes, $0.2 \mathrm{~g}$ of leaf dry matter and $20 \mathrm{~mL}$ of deionised water were placed. The tubes were kept in a water bath at $60 \pm 5^{\circ} \mathrm{C}$ for one hour, during which time shaking was performed every 15 minutes. The samples were filtered on fast filter paper. From this extract, $5 \mathrm{~mL}$ was taken and $20 \mathrm{~mL}$ deionized water and $0.2 \mathrm{~g} \mathrm{MgO}$ were added to it. A first distillation was made to convert ammonium to ammonia and the distillate was discarded. Then, in the same extract, $0.4 \mathrm{~g}$ of Devarda alloy was added to reduce nitrate into ammonium, which in an alkaline medium is converted into ammonia, which is entrained by the vapours, and collected in a beaker containing $10 \mathrm{~mL}$ of $\mathrm{H}_{3} \mathrm{BO}_{3} 20 \mathrm{~g} \mathrm{~L}^{-1}$ solution. Then, the quantification of ammonium $\mathrm{N}$ was performed by automatic titrator (848 Titrino plus) with a standardised solution of $0.00263 \mathrm{~mol} \mathrm{~L}^{-1} \mathrm{H}_{2} \mathrm{SO}_{4}$. The nitrate content obtained in the dry mass of leaves was converted to $\mathrm{mg} \mathrm{kg}^{-1}$ of $\mathrm{NO}_{3}{ }^{-}$in the fresh mass.

\section{Statistical analysis}

Data analysis of variance, F-test, was performed for each experiment and also joint analysis of the experiments. The difference between the experiments was verified by the significance of the F-test. When the $\mathrm{N}$ rate factor was significant, a regression study was performed, adopting the equation with the highest significance and coefficient 
of determination. Statistical analyses were processed using the AgroEstat statistical program (BARBOSA; MALDONADO JÚNIOR, 2015).

\section{RESULTS AND DISCUSSION}

There was no interaction of $\mathrm{N}$ and season on plant height and leaf area, which were influenced only by the factors individually, except for the number of leaves, which had no influence of the evaluated factors (Table 2).

The $\mathrm{N}$ is a nutrient known to determine, in general, major changes in plants, both in terms of growth, productivity and quality of the product to be consumed. In the present study, all these effects of $\mathrm{N}$ on arugula were observed.

Plant height and leaf area increased up to 210 and $198 \mathrm{~kg} \mathrm{ha}^{-1}$ of $\mathrm{N}$, when plants were $33.9 \mathrm{~cm}$ and $468.0 \mathrm{~cm}^{2}$, respectively, while non-N fertilized plants were $26.0 \mathrm{~cm}$ and $251.6 \mathrm{~cm}^{2}$ (Figure 1A and 1B).

Table 2. Summary of joint variance analysis for the variables plant height (PH), number of leaves (NL), leaf area (LA), shoot dry mass $(\mathrm{SDM})$, nitrate content $\left(\mathrm{NO}_{3}{ }^{-}\right)$, nitrogen content $(\mathrm{N})$ by plant and yield $(\mathrm{Y})$ of arugula as a function of nitrogen rates in summer and autumn seasons.

\begin{tabular}{|c|c|c|c|c|c|c|c|}
\hline Sources of variation & PH & NL & LA & SDM & $\mathrm{N}$ & $\mathrm{Y}$ & $\mathrm{NO}_{3}^{-}$ \\
\hline & \multicolumn{7}{|c|}{$\mathrm{F}$ values } \\
\hline Treatments $(\mathrm{T})$ & $28.03 * *$ & $4.66^{\mathrm{ns}}$ & $11.29 * *$ & $2.76^{\mathrm{ns}}$ & $1.51^{\mathrm{ns}}$ & $10.38^{*}$ & $6.87 *$ \\
\hline Seasons (S) & $117.37 * *$ & $4.52^{\mathrm{ns}}$ & $42.59 * *$ & $4.25^{\mathrm{ns}}$ & $0.38^{\mathrm{ns}}$ & $42.24 * *$ & $41.52 * *$ \\
\hline $\mathrm{T} \times \mathrm{S}$ & $0.69^{\mathrm{ns}}$ & $1.42^{\mathrm{ns}}$ & $1.11^{\mathrm{ns}}$ & $11.31 * *$ & $7.13 * *$ & $2.71 *$ & $6.70 * *$ \\
\hline & & & CV (\%) & & & & \\
\hline Summer & 8.7 & 16.1 & 19.9 & 13.4 & 8.8 & 16.3 & 17.7 \\
\hline \multirow[t]{3}{*}{ Autumn } & 4.3 & 7.3 & 8.9 & 9.7 & 3.4 & 14.3 & 11.8 \\
\hline & \multicolumn{7}{|c|}{ Averages } \\
\hline & $\mathrm{cm}$ & leaves/pl & $\mathrm{cm}^{2} / \mathrm{pl}$ & $\mathrm{g} / \mathrm{pl}$ & $\mathrm{g} \mathrm{kg}^{-1}$ & $\mathrm{~kg} \mathrm{~m}^{-2}$ & $\mathrm{mg} \mathrm{kg}^{-1}$ \\
\hline Summer & 28.6 & 10.0 & 466.9 & 4.3 & 24.4 & 3.5 & 3347.5 \\
\hline Autumn & 34.0 & 9.1 & 329.7 & 3.2 & 25.2 & 2.1 & 1663.1 \\
\hline
\end{tabular}

** and $*$ Significant to $1 \%$ and $5 \%$ of probability by F-test, respectively; ${ }^{\text {ns }}$ non significant.

Increasing rates of $\mathrm{N}$ to arugula reflected positively on $\mathrm{N}$ leaf content and thus, higher and desirable values of plant height and leaf area and shoot dry mass were obtained. A great promoter effect on these characteristics was noted between the non-supply of $\mathrm{N}$ and rates that provided their maximum values, which showed positive impacts on height $(30 \%)$ and leaf area $(86 \%)$, shoot dry mass increased by $133 \%$ and $140 \%$ in summer and autumn, respectively. But the arugula yield answered differently as the season. In the autumn, an increment of only $10 \%$ was observed when the $\mathrm{N}$ rate increased from 125 to $213 \mathrm{~kg} \mathrm{ha}^{-1}$ of $\mathrm{N}$ (maximum yield), while, in the summer, for the same rate range it was observed $40 \%$ of increment on arugula yield.

The shoot dry mass of the arugula was influenced by the interaction of the factors, $\mathrm{N}$ rates and growing seasons (Table 2). In response to the increased $\mathrm{N}$ supply to the arugula, in summer, there was a linear increase in shoot dry mass, while in the autumn there was a quadratic equation adjustment with a maximum of $168 \mathrm{~kg} \mathrm{ha}^{-1} \mathrm{~N}$ (Figure 1C). 

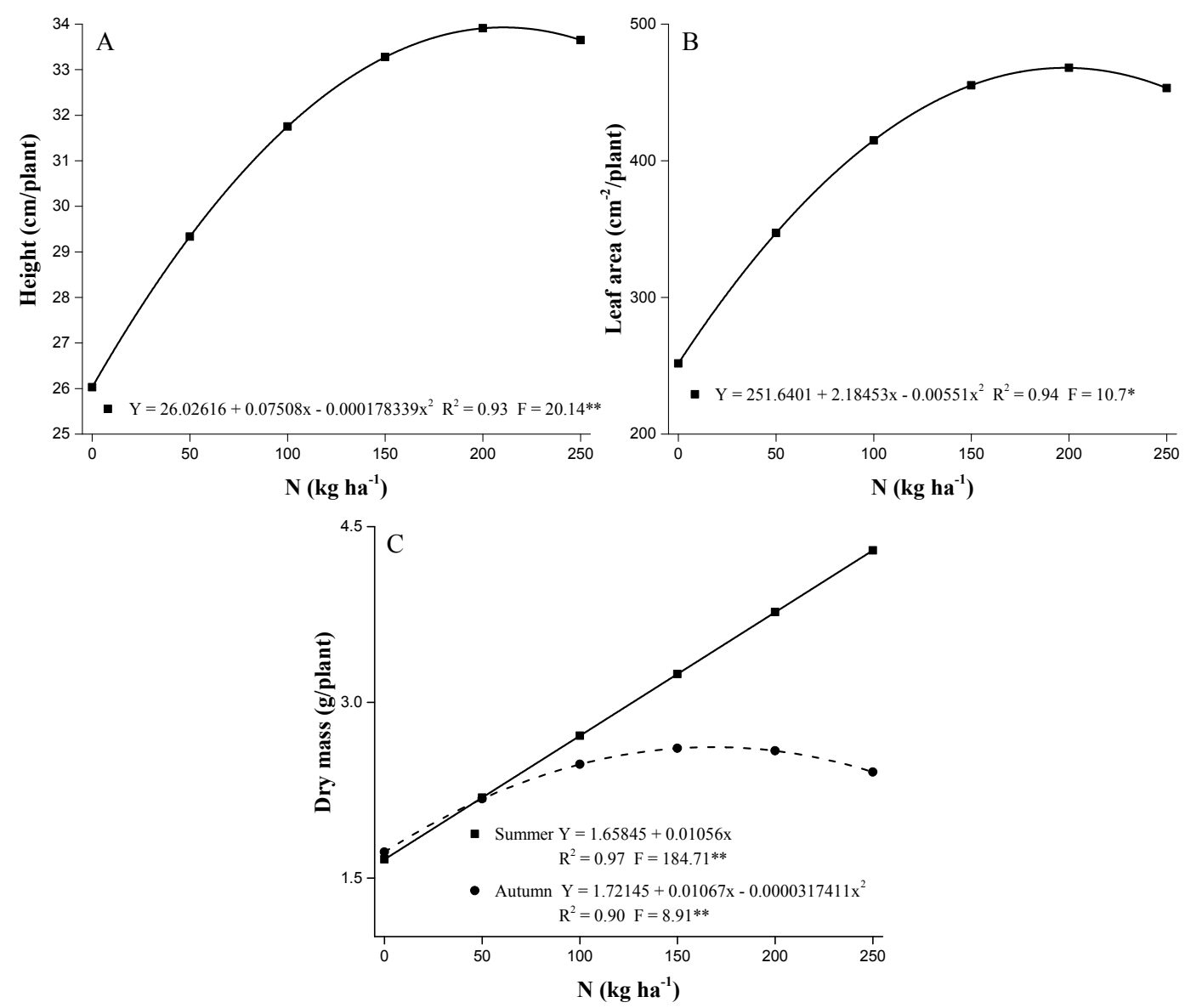

Figure 1. (A) Height and (B) leaf area as a function of nitrogen rate and (C) dry mass of 'Folha Larga' arugula as a function of the growing season and nitrogen rate interaction. $(*, * *$ correspond to significance by $\mathrm{F}$-test at $5 \%$ and $1 \%$ of probability, respectively).

For leaf $\mathrm{N}$ content and arugula yield, there was an interaction between $\mathrm{N}$ rate and growing season (Table 2). In both growing seasons, maximum $\mathrm{N}$ content was verified with the highest rate evaluated $\left(250 \mathrm{~kg} \mathrm{ha}^{-1}\right.$ de $\mathrm{N}$ ) (Figure 2A). Regarding yield, maximums of 4.9 and $2.6 \mathrm{~kg} \mathrm{~m}^{-2}$ were recorded with 250 and $213 \mathrm{~kg} \mathrm{ha}^{-1}$ of $\mathrm{N}$ in summer and autumn, respectively. When not fertilized with $\mathrm{N}$, the yields were 2.1 and $1.1 \mathrm{~kg} \mathrm{ha}^{-1}$ in the both growing seasons respectively (Figure 2B).
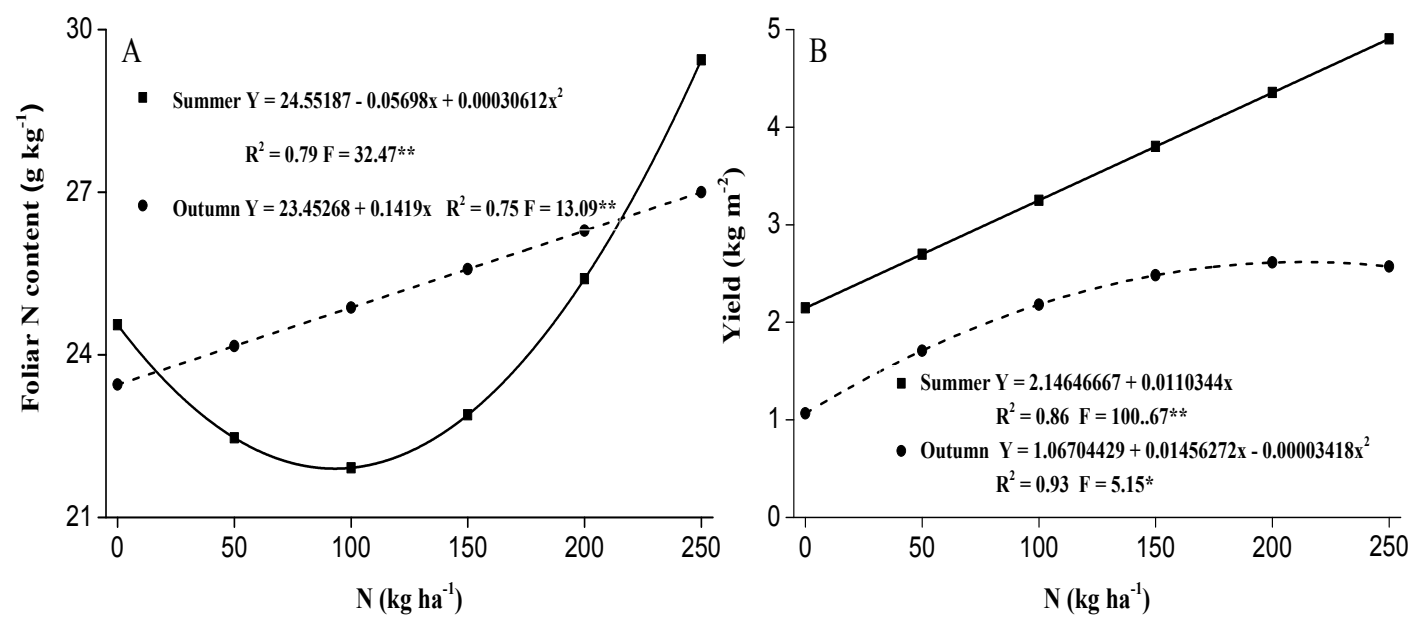

Figure 2. (A) Foliar N content and (B) yield of 'Folha Larga' arugula as a function of the growing season and nitrogen rate interaction. $(*, * *$ correspond to significance by $\mathrm{F}$-test at $5 \%$ and $1 \%$ of probability, respectively). 
The rates found to maximize arugula yield were close to the 248.2 (PURQUERIO et al., 2007) and 240 (BENETT et al., 2019) $\mathrm{kg} \mathrm{ha}^{-1} \mathrm{~N}$ to maximize the productivity of arugula, when it was cultivated in the field. The results corroborate information that arugula is very responsive to $\mathrm{N}$ fertilization (SILVA et al., 2020; STEINER et al., 2011). On the other hand, the $N$ rates evaluated in our study to get great arugula performance are higher than those recommended by Trani et al. (2018) which have range of $110-190 \mathrm{~kg} \mathrm{ha}^{-1}$ of $\mathrm{N}$ total (planting and covering) for arugula crop. According to this recommendation of fertilization for many vegetables crops, the arugula yields would be 3.3 to $4.2 \mathrm{~kg} \mathrm{~m}^{-2}$ in the summer and 2.3 to $2.6 \mathrm{~kg} \mathrm{~m}^{-2}$ in the autumn. Thus, the losses in relation to the maximum obtained which could reach $32 \%$ in the summer would be only of $11 \%$ in the autumn.

The maximum yields were related with 29.4 and $27.0 \mathrm{~g} \mathrm{~kg}^{-1}$ of $\mathrm{N}$ in the shoot dry mass. The difference in polynomial adjustment for the averages of the arugula $\mathrm{N}$ foliar content in the two growing seasons can be explained by the effect of dilution of the nutrient phenomenon (ANDRIOLO et al., 2006), in addition to the arugula response in the accumulation of shoot dry mass (Figure 1C). When not fertilized, the arugula produced a small amount of shoot dry mass. As increased the $\mathrm{N}$ rate, the shoot dry mass produced was greater per accumulated $\mathrm{N}$ unit. This occurred for rates between 0 and around $100 \mathrm{~kg} \mathrm{ha}^{-1}$ of $\mathrm{N}$ reducing at higher rates. Trani et al. (2014) considered $\mathrm{N}$ contents between 40 and $50 \mathrm{~g}$ $\mathrm{kg}^{-1}$ as suitable for arugula; however, these contents were obtained between half and two thirds of the cycle. However, in both growing seasons, no visual symptoms of deficiency of yellow old leaves were observed, even in the treatment with no $\mathrm{N}$ application.

The increase in $\mathrm{N}$ supply had a positive effect on arugula yield, on the other hand, there was also a promoter effect on nitrate increase in the plant, in agreement with that observed by NurzyńskaWierdak (2009).

An interaction of the growing season and $\mathrm{N}$ rate in the nitrate content in the shoot fresh mass of the arugula was verified (Table 1). In summer, leaf contents were much lower than those observed in autumn, regardless of $\mathrm{N}$ rate. However, in both seasons, it was found that the higher the $\mathrm{N}$ rate, the higher the nitrate content in the arugula leaves (Figure 3).

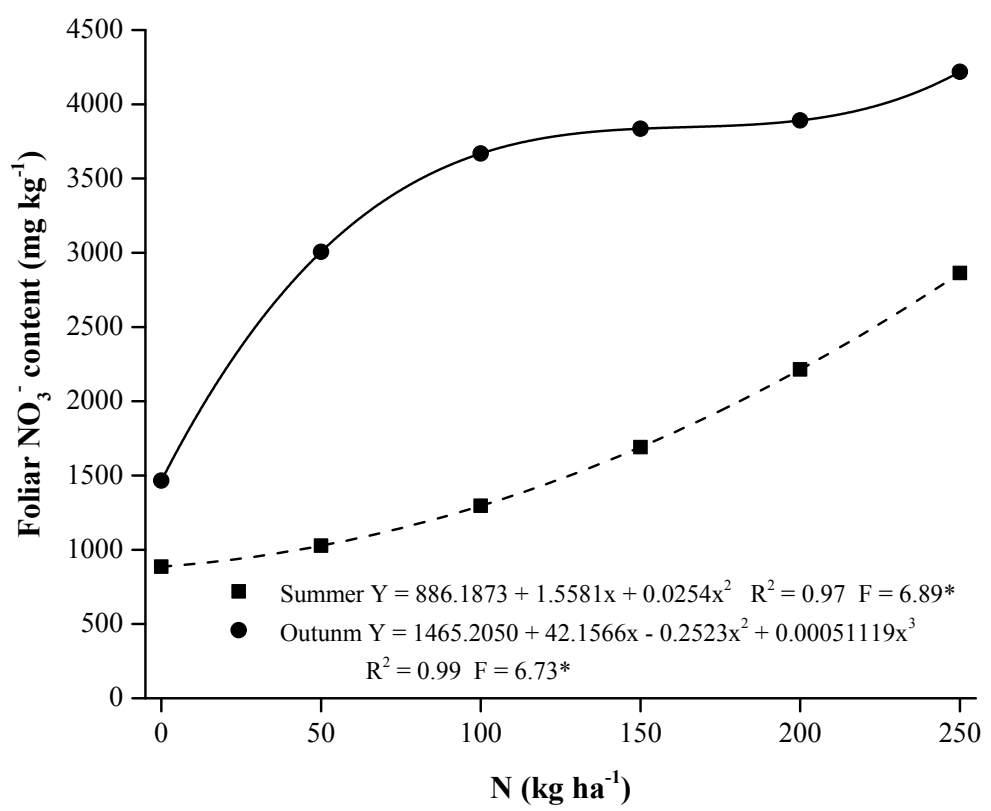

Figure 3. Nitrate content in leaves of 'Folha Larga' arugula as a function of the growing season and nitrogen rate interaction. (* significant by the F-test at $5 \%$ ).

Nitrate content in arugula is an attribute that may compromise the quality of the vegetables, since, according to Maynard et al. (1976), Khan et al. (2013) and Ollúa, Logegaray and Chiesa (2016), that this compound is associated with the possibility of formation of carcinogenic and mutagenic compounds in the human organism.

The maximum nitrate content (4218.4 $\mathrm{mg} \mathrm{kg}^{-1}$ ) in shoot fresh mass of arugula was achieved with $250 \mathrm{~kg} \mathrm{ha}^{-1}$ of $\mathrm{N}$, in autumn. In summer, the maximum level was $2931.3 \mathrm{mg} \mathrm{kg}^{-1}$ also with the highest N. Purquerio et al. (2007) 
evaluated $\mathrm{N}$ rates in arugula $\left(0\right.$ to $\left.240 \mathrm{~kg} \mathrm{ha}^{-1} \mathrm{~N}\right)$ and also reported increases in nitrate accumulation up to the highest evaluated rate, being 1360 and $1290 \mathrm{mg} \mathrm{kg}^{-1}$ in shoot fresh mass of arugula cultivated in field and protected environments, respectively. The result corroborates the claim that crop management is an important factor in the quality of vegetables, especially related to nitrate accumulation (LIU et al., 2014; STAGNARI; GALIENI; PISANTE, 2015; AHMED et al., 2017). $\mathrm{N}$ rate is one of the main factors that promotes higher accumulation of nitrate (MAYNARD et al., 1976; CEYLAN et al., 2002). Higher solar radiation and temperature present in summer growing (Table 1) favoured lower $\mathrm{N}$ accumulation than in autumn cultivation. Cometti et al. (2011), evaluating shading and $\mathrm{N}$ rates in lettuce, found that the lower the radiation, the greater the nitrate accumulation by lettuce.

The results agree with those obtained by Steiner et al. (2011), who also found low nitrate content in arugula (430 to $1400 \mathrm{mg} \mathrm{kg}^{-1}$ ) and with Cometti et al. (2011) for lettuce. Thus, although the increase in $\mathrm{N}$ supply increased by $223 \%$ in summer and $187 \%$ in autumn the nitrate content of arugula leaves compared to plants not fertilized with $\mathrm{N}$, the observed content is below the limit $\left(7000 \mathrm{mg} \mathrm{kg}^{-1}\right)$ proposed by European Union (2011). Even with the high $\mathrm{N}$ rate, the nitrate levels observed were below the proposed limit and can be explained by the climatic conditions of the experimental periods (Table 1).

Higher summer temperatures, solar radiation and precipitation favour plant metabolism and nitrate assimilation (MAYNARD et al., 1976; COMETTI et al., 2011). Thus, from the point of view of the quality of arugula, it is possible to recommend the maximum $\mathrm{N}$ rate evaluated $\left(250 \mathrm{~kg} \mathrm{ha}^{-1}\right)$ in summer and $213 \mathrm{~kg} \mathrm{ha}^{-1}$ of $\mathrm{N}$ in autumn for fertilization of the crop, giving maximum yields in these seasons without compromising the quality of the vegetables.

\section{CONCLUSION}

The supply of $250 \mathrm{~kg} \mathrm{ha}^{-1}$ of $\mathrm{N}$ to arugula in summer and $213 \mathrm{~kg} \mathrm{ha}^{-1}$ of $\mathrm{N}$ in autumn provides substantial increases in height, leaf area, shoot dry mass and yield without compromising quality evaluated by nitrate content in leaves.

\section{ACKNOWLEDGMENTS}

This study was financed in part by the Coordenação de Aperfeiçoamento de Pessoal de Nível Superior - Brasil (CAPES) - Finance Code 001, by scholarship to the first author, and to CNPq by researcher-scholarship to the second author.

\section{REFERENCES}

AGUIAR JÚNIOR, R. A. et al. Interferência de rates de nitrogênio na produção de área foliar, biomassa fresca e seca de rúcula. Horticultura Brasileira, 28: 3970-3974, 2010.

AHMED, M. et al. Excessive use of nitrogenous fertilizers: an unawareness causing serious threats to environment and human health. Environmental Science and Pollution Research, 24: 26983-26987, 2017.

ANDRIOLO, J. L. et al. Curva crítica de diluição de nitrogênio da cultivar Asterix de batata. Pesquisa Agropecuária Brasileira, 41: 1179-1184, 2006.

BARBOSA, J. C.; MALDONADO JÚNIOR, W. Experimentação agronômica \& AgroEstat: sistemas para análises estatísticas de ensaios agronômicos. 1. ed. Jaboticabal, SP: Gráfica Multipress Ltda, 2015. 396 p.

BARROS JÚNIOR, A. P. et al. Nitrate accumulation in lettuce and rocket in response to nitrogen fertilization in intercropping. Revista Caatinga, 33: 260-265, 2020.

BENETT, K. S. S. et al. Nitrogen Application in Arugula Culture. Journal of Agricultural Science, 11: 385-391, 2019.

CEYLAN, S. et al. Effects of different nitrogen levels on the yield and nitrogen accumulation in the rocket. Asian Journal of Plant Sciences, 1: 482 483, 2002.

COMETTI, N. N. et al. Nitrate concentration in lettuce leaves depending on photosynthetic photon flux and nitrate concentration in the nutrient solution. Horticultura Brasileira, 29: 548-553, 2011.

EUROPEAN UNION (UE). Commission Regulation (EC) No 1258/2011 of 2 December 2011 amending Regulation (EC) No 1881/2006 as regards maximum levels for nitrates in foodstuffs setting. Official Journal of the European Union, 320: 15-17, 2011. Available in: <https://eur-lex.europa.eu/LexUriServ/ LexUriServ.do?uri=OJ:L:2011:320:0015:0017:EN: PDF>. Access in: May 302020.

GRANGEIRO, L. C. et al. Crescimento e acúmulo de nutrientes em coentro e rúcula. Revista Brasileira de Ciências Agrárias, 6: 11-16, 2011.

KHAN, S. et al. Drinking water quality and human health risk in Charsadda district, Pakistan. Journal of cleaner production, 60: 93-101, 2013. 
LIU, C. W. et al. Effects of nitrogen fertilizers on the growth and nitrate content of lettuce (Lactuca sativa L.). International journal of environmental research and public health, 11: 4427-4440, 2014.

MANTOVANI, J. R. et al. Comparação de procedimentos de quantificação de nitrato em tecido vegetal. Pesquisa Agropecuária Brasileira, 40: 5359, 2005.

MAYNARD, D. N. et al. Nitrate accumulation in vegetables. In Advances in Agronomy, 28: 71-118, 1976.

MIYAZAWA, M. et al. Análises químicas de tecido vegetal. In: SILVA, F. C. (Eds.). Manual de análises químicas de solos, plantas e fertilizantes. 2. ed. Brasília, DF: Embrapa, 2009. cap. 1, p. 190223.

NASCIMENTO, M. V. et al. Manejo da adubação nitrogenada nas culturas de alface, repolho e salsa. Journal of Neotropical Agriculture, 4: 65-71, 2017.

NURZYŃSKA-WIERDAK, R. Growth and yield of garden rocket (Eruca sativa Mill.) affected by nitrogen and potassium fertilization. Acta Scientiarum polonorum, Hortorum Cultus, 8: 2333, 2009.

OLLÚA, R. T.; LOGEGARAY, V. R.; CHIESA, Á. Concentración de nitratos en dos tipos comerciales de lechuga (Lactuca sativa L.) cultivadas con distintas fuentes nitrogenadas. Chilean journal of agricultural \& animal sciences, 32: 194-203, 2016.

PURQUERIO, L. F. V. et al. Efeito da adubação nitrogenada de cobertura e do espaçamento sobre a produção de rúcula. Horticultura Brasileira, 25: 464-470, 2007.

QADIR, O. et al. Manipulation of contents of nitrate, phenolic acids, chlorophylls, and carotenoids in lettuce (Lactuca sativa L.) via contrasting responses to nitrogen fertilizer when grown in a controlled environment. Journal of Agricultural and Food Chemistry, 65: 10003-10010, 2017.

REZENDE, B. L. A. et al. Custo de produção e rentabilidade das culturas de alface, rabanete, rúcula e repolho em cultivo solteiro e consorciadas com pimentão. Ciência e Agrotecnologia, 33: 305-312, 2009.

REZENDE, B. L. A. et al. Viabilidade econômica das culturas de pimentão, repolho, alface, rabanete e rúcula em cultivo consorciado, na primavera-verão,
Jaboticabal, estado de São Paulo. Informações Econômicas, 35: 1-16, 2005.

SANTOS H. G. et al. Sistema brasileiro de classificação de solos. 5. ed. Brasília, DF: EMBRAPA, 2018. 355 p.

STAGNARI, F.; GALIENI, A.; PISANTE, M. Shading and nitrogen management affect quality, safety and yield of greenhouse-grown leaf lettuce. Scientia Horticulturae, 192: 70-79, 2015.

SILVA, P. H. S. et al. Nitrogen levels via fertigation and irrigation depths in the arugula culture. Horticultura Brasileira, 38: 343-349, 2020.

STEINER, F. et al. Produção de rúcula e acúmulo de nitrato em função da adubação nitrogenada. Revista Brasileira de Ciências Agrarias, 6: 230-235, 2011.

TRANI, P. E. et al. Calagem e adubação da alface, almeirão, agrião d'água, chicória, coentro, espinafre e rúcula. Campinas: IAC, 2014. Disponível em: <http://www.iac.sp.gov.br/ imagem informacoestecnologicas/97.pdf $>$. Acesso em: 10 jan. 2017

TRANI, P. E. et al. Composição química e diagnose foliar, in: TRANI, P. E. et al. (Eds.). Hortaliças: recomendações de calagem e adubação para o Estado de São Paulo. Campinas: CATI, 2018, p. 8-13.

TRANI, P. E.; PASSOS, F. A.; AZEVEDO FILHO, J. A. Alface, almeirão, chicória, escarola, rúcula e agrião d'agua. In: RAIJ, $B$. van et al. (Eds.). Recomendação de adubação e calagem para o estado de São Paulo (Boletim Técnico, 100). 2. ed. Campinas, SP: Instituto Agronômico, 1997. cap. 18, p. 168-169.

WANG, T. et al. Green synthesized iron nanoparticles by green tea and eucalyptus leaves extracts used for removal of nitrate in aqueous solution. Journal of Cleaner Production, 83: 413419, 2014

WARD, M. H. Too Much of a Good Thing? Nitrate from Nitrogen Fertilizers and Cancer. Reviews on environmental health, 24: 357-363, 2009. 